\title{
Geothermal Energy Potential of the Chad Basin, North-Eastern Nigeria
}

\section{*1LAWAL, TO; ${ }^{2}$ NWANKWO, LI; ${ }^{1}$ IWA, AA $;{ }^{3}$ SUNDAY, JA; ${ }^{1}$ OROSUN, MM}

\author{
${ }^{1}$ Department of Physics, ${ }^{2}$ Department of Applied Geophysics, University of Ilorin, Ilorin, Nigeria \\ ${ }^{3}$ Department of Science Laboratory Technology, Kwara State Polytechnic Ilorin \\ *Corresponding Author Email: taofeeqlawal4u@gmail.com
}

\begin{abstract}
In this research paper, the sub-surface heat flow of a part of the Chad Basin, in North eastern Nigerian was estimated using spectral analysis. This was obtained from twenty (20) digitized High Resolution Aeromagnetic (HRAM) data sheet covering the study area. Regional-residual separation using first order polynomial fitting method with three coefficients was carried out on the data map before the application of statistical spectral analysis. Result shows that the centroid depth varies between $9.39 \mathrm{~km}$ and $18.31 \mathrm{~km}$. The depth to the Curie temperature isotherm varies between $15.14 \mathrm{~km}$ and $33.46 \mathrm{~km}$ below the mean sea level. It was also found that the Curie temperature isotherm within the basin is not a horizontal level surface but an undulating surface with geothermal gradients and heat flow ranging between 15.77 and $38.31^{\circ} \mathrm{C} / \mathrm{Km}$, and 39.41 and $95.77 \mathrm{mWm}^{-2}$ respectively. Thus, the calculated average geothermal gradient and heat flow for this area are $23.39^{\circ} \mathrm{C} / \mathrm{Km}$ and $58.47 \mathrm{~mW} \mathrm{~m}^{-2}$ respectively. Since average heat flow in thermally normal continental region is $60 \mathrm{mWm}^{-2}$ and the values in excess of $80 \mathrm{mWm}^{-2}-100 \mathrm{mWm}^{-2}$ are associated with anomalous geothermal conditions, hence the study area can generally be considered as a thermally normal region. But, the northeastern part of the study area with values in excess of $80 \mathrm{mWm}^{-2}$ is recommended for further investigation.
\end{abstract}

\section{DOI:https://dx.doi.org/10.4314/jasem.v22i11.17}

Copyright: Copyright $\odot 2018$ Lawal et al. This is an open access article distributed under the Creative Commons Attribution License (CCL), which permits unrestricted use, distribution, and reproduction in any medium, provided the original work is properly cited.

Dates: Received: 04 July 2018; Revised: 26 October 2018; Accepted 10 November 2018

Keywords: Geothermal energy, Spectral Analysis, Chad Basin. Curie point depth

Nigeria is a country with insufficient generation of electricity for the consumption of the populace at large despite continue increase in population in Nigeria, the need for more power both for domestic and industrial use. There has never been a more urgent time to look into generation of electric power generation from other sources to complement the ones being used despite the fact that geothermal source of energy has been successively annexed in some countries in Africa and world at large, Nigeria as a country cannot be exempted from the possibility of exploring geothermal energy (Ewa and Kryrowska 2010).Geothermal energy refers to the use of heat energy within the earth where earth's heat engine is driven by cooling of the crust and heating of the lower crust and mantle by thermal decay of radioactive isotopes, therefore the deeper below the surface, the hotter the temperature is (W.E.C, 2016). Some studies have been carried out on geothermal potential in different basins and geological area in Nigeria (Ewa and Kryrowska, 2010;Lawal and Nwankwo, 2017; Nwankwo and Shehu, 2015; and Nwankwo, L.I., 2015).Ewa and Kryrowska (2010) and Nwankwo et al.,(2009) reported that geothermal gradient values ranging from $34{ }^{\circ} \mathrm{C} / \mathrm{km}$ to $59{ }^{\circ} \mathrm{C} / \mathrm{km}$ were obtained during a temperature data analysis from wire line logs of 14 shallow water wells which are about $500 \mathrm{~m}$ deep in areas covering part of Chad basin. In Sokoto basin located in northwestern part of Nigeria's geothermal gradient of $52.11^{\circ} \mathrm{C} / \mathrm{km}$ was obtained using magnetic data of the entire basin (Nwankwo and Shehu, 2015).Abraham et al.,(2015) estimated a value of $54.11^{\circ} \mathrm{C} / 100 \mathrm{~K}$ as the average geothermal gradient of the region around Wikki Warm Spring (WWS) using aeromagnetic data of the upper Benue trough. In the Niger-Delta region of the country Adedapo et al.,(2009) and Emujakporue and Ekine (2014) reported a result from the analysis of subsurface temperature where a minimum geothermal gradient of $1.2{ }^{\circ} \mathrm{C} / 100 \mathrm{~m}$ at the central part of the basin and a maximum of $7.62{ }^{\circ} \mathrm{C} / 100 \mathrm{~m}$ at the northeastern part of the basin were obtained. Chukwu et al., (2017) also carried out an analysis of geothermal energy potential using aeromagnetic data of part of Niger delta and obtain geothermal and heat flow values ranging from 12.26 to $40.19^{\circ} \mathrm{C} / \mathrm{km}$ and 25.30 to $84.40 \mathrm{~mW} / \mathrm{m}^{2}$. They concluded that since the heat flow value is below $100 \mathrm{~mW} / \mathrm{m}^{2}$, the area may not feasible as a geothermal energy source. In view of the above literature from researchers on geothermal potential in Nigeria and Africa at large, an analysis of aeromagnetic data of part of Chad basin for 
geothermal energy potential was carried out in other to complement the existing work done in the area.

\section{MATERIALS AND METHODS}

Location and Geology of the Study Area: The study area which is a part of Chad basin Nigeria is bounded by $11^{\circ} \mathrm{N}-14^{\circ} \mathrm{N}$ and longitudes $9^{\circ} \mathrm{E}-14^{\circ} \mathrm{E}$ covering states such as Borno, Yobe and Adamawa (Fig. 1). It covers an area of about 59,901 square kilometers. Olugbemiro et al., (1997) reported that the Nigeria sector of Chad basin is bounded to the east by the Mandara Mountains and in the south by the Benue trough and Biu Plateau. It encompasses the southeastern portion of the basin which is situated in a tectonically energetic area with features which spreads northwest to the Air Plateau and Southwest towards the Benue trough, the third and unsuccessful arm of a three-layered rift joint developed as a result of the separation of African and South American plates in early Cretaceous times (Carter et al., 1963). Geologically, the basin, which houses the study area has been described by many authors (Nur 2001; Obaje 2009; Odebode 2010; Lawal and Nwankwo, 2017). This basin is believed to be a broad sediment-filled depression stranding Northeastern Nigeria and adjourning parts of Chad Republic. The sedimentary rocks have a cumulative thickness of over $3.6 \mathrm{~km}$ and consist of thick basal continental sequence and transitional calcareous deposit. It combines with the Sokoto Basin in the west of the Damergou gap between the air and Zinder massifs (Wright et al., 1985). The generalized stratigraphy column of the Basin has been described by (Odebode, 2010) to be of sedimentary sequence made up of Chad Formation,
Kerri-Kerri Formation, Gombe Formation, Fika Shale, Gongila Formation and Bima Sandstone. Sedimentation began in Chad (Bornu) Basin during Upper Cretaceous (probably Uppermost Albian) when over $1000 \mathrm{~m}$ of continental, sparsely fossil ferrous, unwell-organized intermediate to rough grained, Feld spathic sand stone which can be regards to as the Bima Formation were deposited uncomfortably in the Precambrian Basement. Other sedimentary stratigraphy sequences were formed as a result of oceanic intrusion into Chad drainage and extensional deformation that occurred in the basin. The area is marked by two distinct climatic conditions. The rainy season lasts usually from May to September with an average temperature of $30-46{ }^{\circ} \mathrm{C}$ depending on the rainfall pattern for the particular year. The dry season heralded annually by the dry, dusty Harmattan winds which blows off the Sahara desert, occurs between October and April with an average temperature of 30$37{ }^{\circ} \mathrm{C}$. The mean annual rainfall is $7.8 \mathrm{~mm}$ and a relative humidity of an about $50-80 \%$. The vegetation, which is predominantly of the Savannah-type, is divided in to two zones: Sahel Savannah towards the north and Sudan Savannah to the south.

There are different methods of estimating depth to the bottom of magnetic sources, which is also a proxy for Curie Point Depth (CPD) Salk et al (2005). But for this study, Spectral analysis (centroid method) as proposed by Okubo et al., (1985), to estimate for depth to the bottom of magnetic sources $\left(Z_{b}\right)$, was used. According to Ravat et al., (2007), the centroid method is one of the most commonly used methods because it gives better estimates with less depth errors compared to others.



Fig.1: Map of Nigeria showing the study area (Modified after Obaje 2009). 
The proposal by Okubo et al., (1985) is based on the spectral analysis method of Spector and Grant (1970) and this method is a 2-D spectral analysis magnetic anomaly data which was used to estimate the depth to the top of magnetized rectangular prisms $\left(Z_{t}\right)$ from the slope of the log power spectrum. Bhattacharyya and Leu (1975); (1977) were able to calculate the depth to the centroid of magnetic $\operatorname{sources}\left(Z_{o}\right)$ and the mathematical models of centroid method used in this study are based on the examination of the shape of isolated magnetic anomalies as introduced by (Bhattacharyya and Leu 1975; 1977). Blakely, (1995) introduced power spectral density of total magnetic field, from which Tanaka et al., (1999) showed that the basal depth of magnetic sources can be estimated using equation 3 (below) proposed by Okubo et al., (1985) by calculating the top depth and centroid depth of magnetic sources from the power spectrum of magnetic anomalies. Using equation 1 below, the centroid depth can be calculated by fitting a straight line through the low wave number part of the wave number- power spectrum:

$\ln \left(\frac{\mathrm{P}(\mathrm{k})^{\frac{1}{2}}}{K}\right)=A-|K| Z_{o} \quad 1$

Where $P(k)$ is the azimuthal average power spectrum, $\mathrm{K}$ is the wave number $\left(\mathrm{km}^{-1}\right), \mathrm{A}$ is a constant, and $Z_{o}$ is the basal depth.

Where, $Z_{o}=\frac{m_{o}}{2 \pi} 2$

The depth to the top of magnetic sources is obtained by fitting a straight line through the high wave number part of the power spectrum.

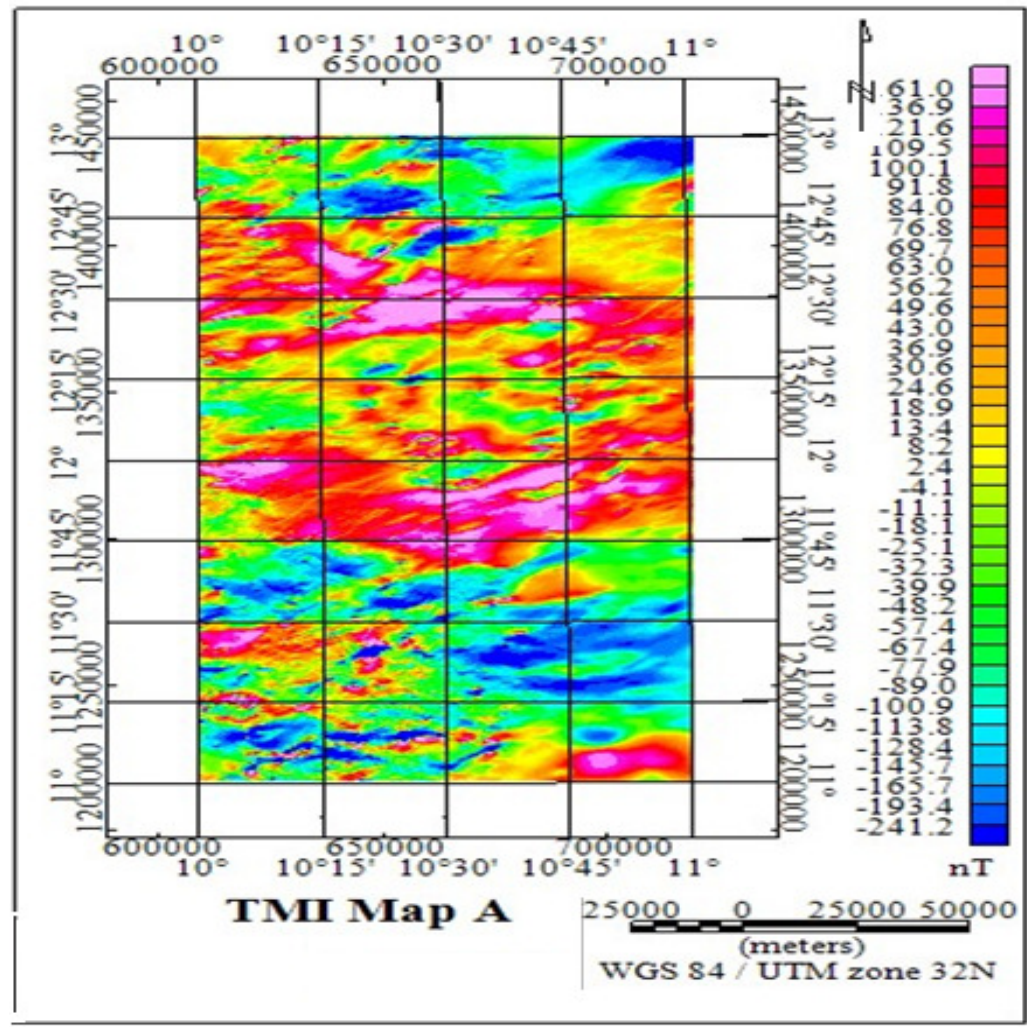

Fig.2. Total Magnetic Intensity (TMI) Map A (First set of obtained aeromagnetic map).

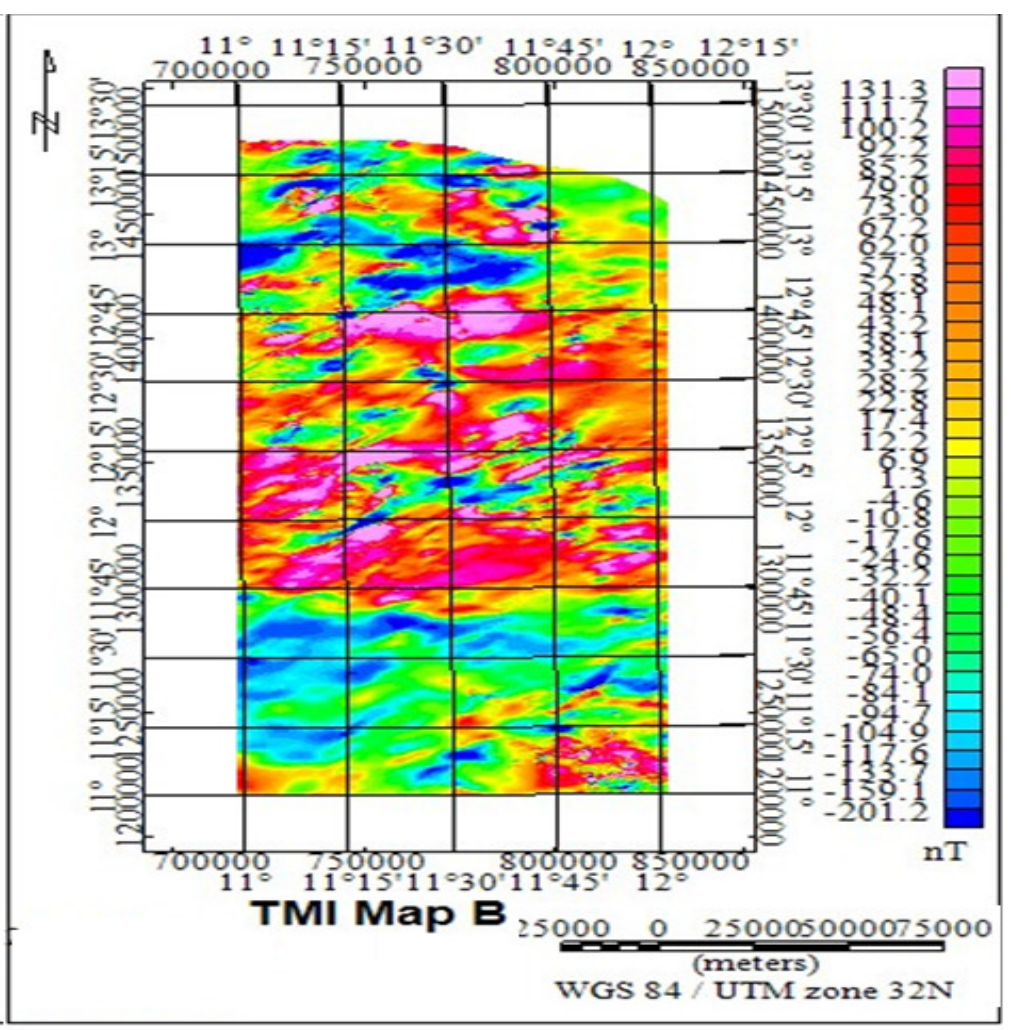

Fig.3. Total Magnetic Intensity (TMI) Map B (Second set of obtained aeromagnetic map). 
$m_{o}$, is the slope of the plot for the depth to the centroid, $Z_{o}$.

$\ln \left(\mathrm{P}(\mathrm{k})^{\frac{1}{2}}\right)=B-|K| Z_{t} \quad 3$

$m_{o}$, is the slope of the plot for the depth to the centroid, $Z_{o}$.

$Z_{t}=\frac{m_{t}}{2 \pi} 4$

$m_{t}$, is the slope of the plot for the depth to the top, $Z_{t}$, B is a constant, and $Z_{t}$ is the depth to the top of magnetic sources.

From the two equations above, the natural logarithm (Ln) of the power spectrum is always plotted against the wave number (K). Where $Z_{t}$ and $Z_{o}$ are the slopes of such plot. Consequently the Depth to the Basal or Bottomof Magnetic Sources (DBMS) or Curie Point Depth (CPD) can be estimated using the relation Okubo et al., (1985).

$Z_{b}=2 Z_{o}-Z_{t} \quad 5$

To calculate the geothermal gradient, $\frac{\mathrm{dT}}{\mathrm{dz}}$ it is assumed that: (i) the surface temperature is 0 ${ }^{\circ} \mathrm{C}$ i.e. no heat sources exit at the surface. (ii) The direction of temperature variation is vertical and the temperature gradient $\frac{\mathrm{dT}}{\mathrm{dZ}}$ is constant and (iii) there is no magnetic source at the CPD.

$$
\frac{\mathrm{dT}}{\mathrm{dz}}=\frac{\theta_{c}}{z_{b}} \quad 6
$$

Where, $\theta_{c}$ is the Curie temperature to be $580^{\circ} \mathrm{C}$ and $\frac{\mathrm{dT}}{\mathrm{dZ}}$ is the geothermal gradient which could only be obtained if the above assumptions $1-3$ are true (Bansal et al. 2011; Nwankwo and Shehu 2015).The heat flow $\left(q_{z}\right)$, can be



Fig.4. Composite Total Magnetic Intensity (TMI) map of the study area (After Knitting)



Fig.5.Residual Field Aeromagnetic Map of the study area. 
calculated from the temperature gradient using the Fourier's (1995) Law

$q_{z}=-k \frac{\theta_{c}}{z_{b}}=-k \frac{\mathrm{dT}}{\mathrm{dz}} \quad 7$

Where, $\mathrm{K}$ is the thermal conductivity and it is assumed be $2.5 \mathrm{Wm}^{-{ }^{1} \mathrm{C}^{-1}}$ (Nwankwo, and Shehu, 2015).

Application to the Magnetic data set:High Resolution Aeromagnetic (HRAM) data covering the study area and published in a map form on a scale of 1:100,000 were procured from Nigerian Geological Survey Agency (NGSA) in two sets of ten sheets each making a total of twenty (20) aeromagnetic maps.

The two data set were then knitted together with the aid of Oasis Montaj software using the blending method. The two data sets and the composite Total Magnetic Intensity (TMI) map obtained after knitting are shown in Fig. 2, 3 and 4 respectively. In order to obtain an accurate DBMS, a regional trend map (Fig.6) was removed from the TMI map (Fig. 4) using a first orderpolynomial equation so that effect of topography and shallow magnetic sources present in the data would be resolved (Saada, 2016) and presented as a residual map (Fig.5).

The residual field data of the study area was divided into ten (10) 50 by 50 overlapping blocks for the purpose of spectral and geothermal analysis (Abraham et al., 2015). The blocks were overlapped to ensure that no data was left out. The average power spectrum of each block was then obtained.Two plots of natural logarithm of the spectral power against their corresponding wave number were made for each block, with the aid of Matlab using a moving average of three points in order to obtain a smoothed plot. Taking the ground surface as a reference zero kilometer, the depth to the top $\left(Z_{t}\right)$, centroid $\left(Z_{o}\right)$, and bottom $\left(Z_{b}\right)$, of magnetic sources for each block were obtained using equations $(1)-(5)$. The obtained depths for each block is presented in Table 1.In other to calculate the geothermal gradient and heat flow of the study area, equation 6 and 7 were used. The obtained depth for each block is presented in Table 2 and their contour plots are shown in Figs. 9 and 10 respectively.

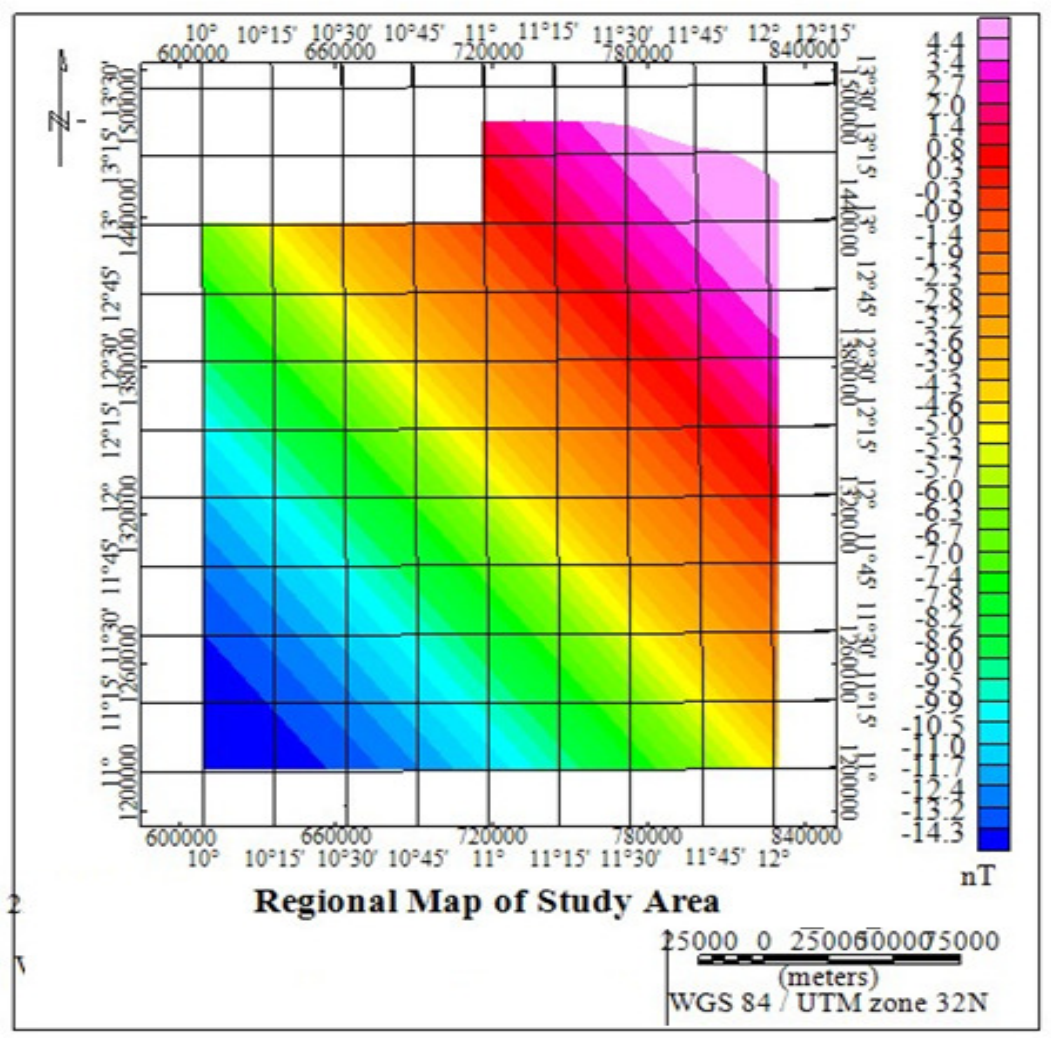

Fig.6. Regional Field Aeromagnetic Map of the study Area.

\section{RESULTS AND DISCUSSION}

The results of the estimated depths for the ten blocks as shown in Table 1, ranges between 1.48 to5.00 $\mathrm{km}$ with an average value $3.33 \mathrm{~km}$, the centroid depth ranges between 9.39 to $20.52 \mathrm{~km}$, with an average of $15 \mathrm{~km}$. The depth to the base of magnetic sources (CPD) varies between $15.14 \mathrm{~km}$ to $36.79 \mathrm{~km}$ with an average depth of $26.68 \mathrm{~km}$. Furthermore, the geothermal gradient was found to vary between 15.77 and $38.31^{\circ} \mathrm{C} / \mathrm{km}$, with an average of $23.39^{\circ} \mathrm{C} / \mathrm{km}$, while the heat flow parameter vary between 39.41 and $95.77 \mathrm{mWm}^{\mathrm{-}^{2}}$, having an average of $58.47 \mathrm{mWm}^{-2}$. In the exploration of sedimentary basins, the general assumption is that intrusive rocks within the crystalline basement complex are truncated by erosion at their surface. Hence, the variation in the depth to the top of magnetic sources obtained from the study area shows a spatial relationship between the sediments overlying the Precambrian basement complex which is characterized by elevations and depressions. The sedimentary thickness obtained is in agreement with previous research work in the study area (Anakwuba and Chinwuko, 2012; Chinwuko et al., 2012; Lawal et al., 2015). 
Table 1: Estimations of Depth to top $\left(Z_{t}\right)$, centroid $\left(Z_{o}\right)$, and bottom (CPD) $\left(Z_{b}\right)$, of magnetic sources from spectral analysis

\begin{tabular}{llllll}
\hline Blocks & Long $\left({ }^{\circ} \mathrm{E}\right)$ & Lat. $\left({ }^{\circ} \mathrm{N}\right)$ & $\begin{array}{l}\text { Depth } \\
\text { totheTop }\left(Z_{t}\right)\end{array}$ & $\begin{array}{l}\text { Depth to the } \\
\text { centroid }\left(Z_{o}\right)(\mathrm{km})\end{array}$ & $\begin{array}{l}\text { Depth tothe } \\
\text { Bottom }\left(Z_{b}\right)(\mathrm{km})\end{array}$ \\
\hline 1 & 10.50 & 12.50 & 2.91 & 12.83 & 22.75 \\
2 & 11.00 & 12.50 & 3.12 & 14.76 & 26.52 \\
3 & 11.50 & 12.50 & 3.64 & 9.39 & 15.14 \\
4 & 11.50 & 12.88 & 4.99 & 11.34 & 17.69 \\
5 & 10.50 & 12.00 & 1.48 & 13.82 & 26.16 \\
6 & 11.00 & 12.00 & 3.47 & 16.92 & 30.33 \\
7 & 11.50 & 12.00 & 2.72 & 16.75 & 30.78 \\
8 & 10.50 & 11.50 & 3.59 & 14.25 & 24.91 \\
9 & 11.00 & 11.50 & 4.25 & 20.52 & 36.79 \\
10 & 11.50 & 11.50 & 3.15 & 19.43 & 35.71 \\
Average & & & 3.33 & 15.00 & 26.68 \\
\hline
\end{tabular}

The depth increases from the central part to the northeast and southern part of the study area. According to Wright (1985), the minimum sedimentary thickness required to attaining a threshold temperature for the beginning of hydrocarbon maturation is $2.3 \mathrm{~km}$. Hence, hydrocarbon exploration is feasible in all parts of the study area except the westcentral part, where a depth is lesser than $2.3 \mathrm{~km}$.For the Curie-point isotherm map (Fig.8), the values trend NE-SW with the shallowest $(15 \mathrm{~km})$ at the northeastern part of the study area, while the deepest $(>30 \mathrm{~km})$ is noticeable at the southeastern part of the study area, this deeper part of the study area extends into the Republic of Chad and Upper Benue trough where similar results have been obtained (Lawal and Nwankwo, 2017; Nur et al., 1999). Lawal and Nwankwo (2017) obtained a depth to base of magnetic sources value ranging between 18.18 and $43.64 \mathrm{~km}$, with an average of $28.70 \mathrm{~km}$.

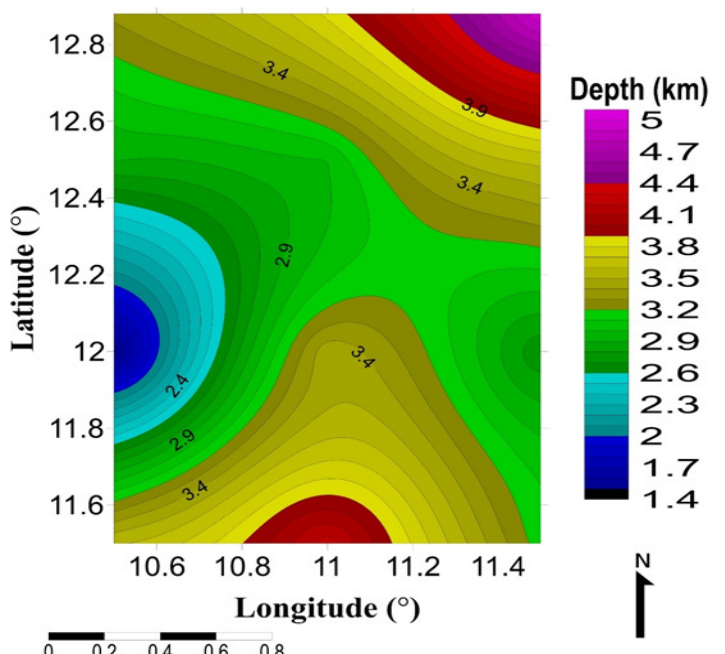

Fig. 7 Depth to the top $\left(Z_{t}\right)$ of magnetic sources contour map (Sedimentary thickness). (Contour interval of $0.1 \mathrm{~km}$ )

It can also be observed from the map that shallow depth to the base of magnetic sources are associated with negative magnetization which corresponds to low magnetic values of the residual map (Salk et al., 2005).

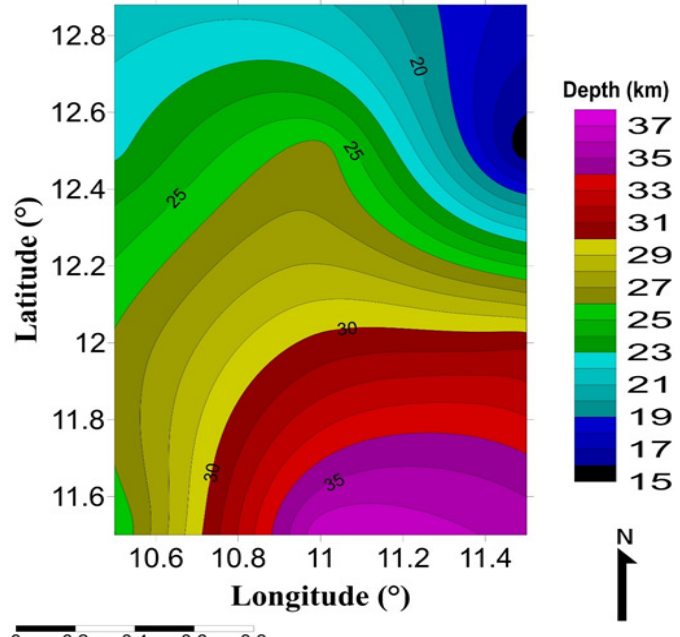

$\begin{array}{llll}0.2 & 0 . \overline{4} \quad 0.6 & 0.8\end{array}$

Fig.8. Curie point depth $\left(Z_{b}\right)$ contour map of the study area (CI $1 \mathrm{~km})$.

Table 2: Geothermal gradient and respective heat flow values of block

\begin{tabular}{llllll}
\hline $\begin{array}{llll}\text { Blocks } \\
\text { Long } \\
\left({ }^{\circ} \mathrm{E}\right)\end{array}$ & $\begin{array}{l}\text { Lat } \\
\left({ }^{\circ} \mathrm{N}\right)\end{array}$ & $\begin{array}{l}\text { Depth to the Geotherma1 } \\
\text { bottom }(\mathrm{km})\end{array}$ & $\begin{array}{l}\text { Heat flow } \\
\text { gradient }\left({ }^{\circ} \mathrm{C} / \mathrm{km}\right) \\
\left(\mathrm{m} / \mathrm{Wm}^{2}\right)\end{array}$ \\
\hline 1 & 10.50 & 12.50 & 22.75 & 25.50 & 63.74 \\
2 & 11.00 & 12.50 & 26.52 & 21.87 & 54.68 \\
3 & 11.50 & 12.50 & 15.14 & 38.31 & 95.77 \\
4 & 11.50 & 12.88 & 17.69 & 32.79 & 81.97 \\
5 & 10.50 & 12.00 & 26.16 & 22.17 & 55.43 \\
6 & 11.00 & 12.00 & 30.33 & 19.12 & 47.81 \\
7 & 11.50 & 12.00 & 30.78 & 18.84 & 47.11 \\
8 & 10.50 & 11.50 & 24.91 & 23.28 & 58.21 \\
9 & 11.00 & 11.50 & 36.79 & 15.77 & 39.41 \\
10 & 11.50 & 11.50 & 35.71 & 16.24 & 40.61 \\
\multicolumn{7}{l}{ Average } & & 26.68 & 23.39 & 58.47 \\
\hline
\end{tabular}

Figure 10 shows the heat flow map of the study area, with the high heat flow $\left(>83 \mathrm{mWm}^{-2}\right)$ corresponding to high geothermal gradient $\left(>33^{\circ} \mathrm{C} / \mathrm{km}\right.$ ) (Fig. 9) and the shallow DBMS at the northeastern part of the study area. While the low heat flow $\left(<47 \mathrm{mWm}^{-2}\right)$ corresponds to the low geothermal gradient $(<18$ ${ }^{\circ} \mathrm{C} / \mathrm{km}$ ) and high DBMS at the southeastern part of the 
study area. Jones (1975) reported that regions of high geothermal gradient could lead to hydrocarbon generation at shallow depth, while regions of low geothermal gradient may not be viable for hydrocarbon exploration except at greater depth. Hence, the northeastern part of the study area with high geothermal gradient and sedimentary thickness would be more feasible for hydrocarbon exploration at a shallow depth. In addition the average value for heat flow obtained $\left(58.47 \mathrm{mWm}^{-2}\right)$ is consistent with that of Anakwuba et al., (2015) who obtained a value of $54.375 \mathrm{~m} / \mathrm{Wm}^{2}$ for an adjoining area.

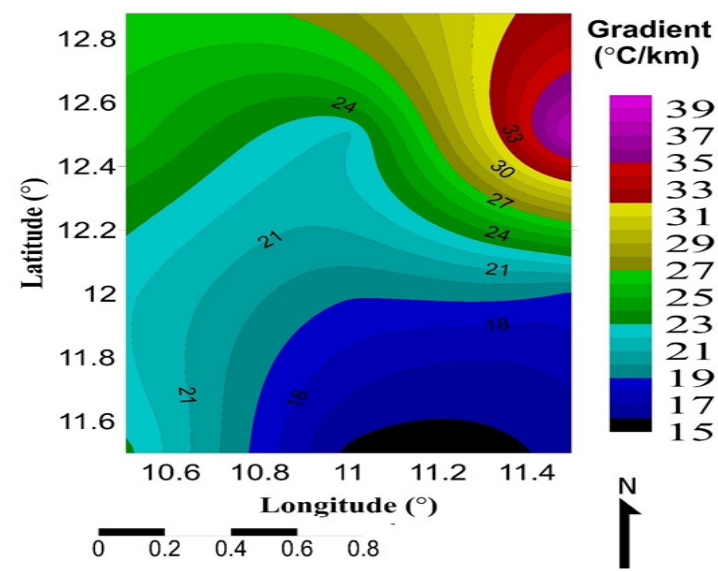

Fig. 9.Geothermal gradient contour map of the study area (CI $\left.1^{\circ} \mathrm{C} / \mathrm{km}\right)$

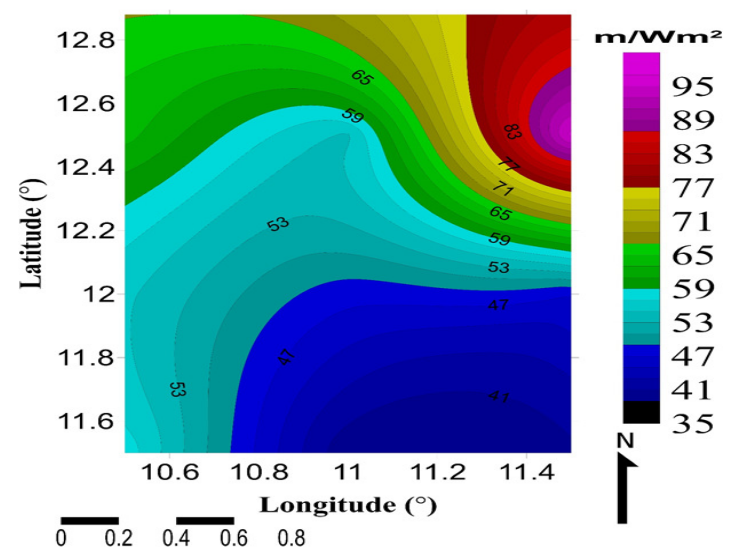

Fig. 10.Surface heat flow map of the study area (Contour interval of $2 \mathrm{~m} / W \mathrm{~m}^{2}$ ).

Lawal and Nwankwo (2017) obtained an average of $54.93 \mathrm{~m} / \mathrm{Wm}^{2}$. It is believed that the estimated geothermal gradient and heat flow values in this study differs from the estimated values from previous works using Borehole data from oil wells in Chad (Bornu)basin (Nwankwo et al., 2009a; 2009b)due to lack of any of such boreholes being located in our study area. In addition, changes in groundwater movement, thermal conductivity of rocks, and endothermic reaction during diagenesis (this increase in thermal energy can be due to pressure) with the added effect of uneven presence of intrusives in the basin can cause the estimated difference.

Conclusion:Evaluation of geothermal energy potential of part of Chad Basin, North-Eastern Nigeria has been carried out. The study has given mathematical information about the geothermal structures of the area. The basis of this study is to contribute to the body of work on geothermal energy potential in the Chad Basin section of Nigeria with the hope that it will lead to energy sufficiency in the country at large. From the results obtained, it is believed that the northeastern part of the study area is a good prospect for geothermal energy exploration. Jessop et al., 1976 proposed a minimum heat flow of $60 \mathrm{~m} / \mathrm{Wm}^{2}$ for considerable generation of geothermal energy values ranging from $80-100 \mathrm{~m} / \mathrm{Wm}^{2}$ and above indicates anomalous geothermal conditions. Since there are values greater than $60 \mathrm{~m} / \mathrm{Wm}^{2}$ in the northeastern part of the map, A more detailed geothermal investigations is required in this part of the area.

\section{REFERENCES}

Abraham, EM; Grace, E; Obande, M; Chukwu, CG; Onwe, MR (2015). Estimating depth to the bottom of magnetic sources at Wikki Warm Spring region, northeastern Nigeria, using fractal distribution of sources approach. Turkish J Earth Sci. 3 (24): 494512.

Adedapo, JO; Kurowska, ES; Ikpokonte, AE (2013). Geothermal gradient of the Niger Delta from recent studies. Inter. J. of Sci. Eng.Research 2 (4): 11- 20.

Ali, S; Orazulike, DM (2010). Well Logs-Derived Radiogenic Heat Production in the Sediment of the Chad Basin, NE Nigeria. J. Applied Sci.1 (3): 13 19

Anakwuba, E; Chinwuko, A (2012). Re-Evaluation of Hydrocarbon Potentials of Eastern Part of the Chad Basin, Nigeria: An Aeromagnetic Approach Adapted from extended abstract prepared in conjunction with poster presentation at $A A P G$ Annual Convention and Exhibition, Long Beach, California.

Anakwuba, EK; Chinwuko, AI (2015). One Dimensional Spectral Analysis and Curie Depth Isotherm of Eastern Chad Basin. Nig. Journal of Nat. Sci. Research (5)19: 12 - 18

Bansal, AR; Gabriel, G; Dimri, VP; Krawczyk, CM (2011). Estimation of depth to the bottom of magnetic sources by a modified centroid method for fractal distribution of sources: An application to 
aeromagnetic data in Germany, Geophysics, 76(3): L11 -L22.

Bhattacharyya, BK; Leu, LK (1977). Spectral analysis of gravity and magnetic anomaliesdue to rectangular prismatic bodies. Geophysics (42): 41-50.

Bhattacharyya, BK; Leu, LK (1975). Analysis of magnetic anomalies over Yellowstone National Park. Mapping the Curie-point isotherm surface for geothermal reconnaissance. J. Geo. Res. (80): 461465 .

Blakely, RJ (1995). Potential Theory in Gravity and Magnetic Applications. Cambridge Univ. Press. 307-308

Chukwu, CG; Udensi, EE; Abraham, E.M; Ekwe, AC; Selemo, AO (2017). Geothermal energy potential from analysis of aeromagnetic data of part of the Niger-delta basin, southern Nigeria. Energy (143):846 - 853 .

Chinwuko, AI; Onwuemesi, AG; Anakwuba, EK; Onuba, LO; Nwokeabia, NC (2012). Interpretation of Aeromagnetic Anomalies over parts of Upper Benue Trough and Southern Chad Basin, Nigeria. A. in Appl Sci. Res. (3):1757-1766.

Cyril, N;Nwankwo, Anthony, S; Ekine, G (2009). Geothermal gradients in the Chad Basin, Nigeria, from bottom hole temperature logs. Int. J of Physical Sci. 4 (12): 777-783.

Emujakporue, GO; Ekine, AS (2014). Determination of Geothermal Gradient in the Eastern Niger Delta Sedimentary Basin from Bottom hole Temperatures. J. of E. Sci. and Geotechnical Eng. (4)3, 2014; 109114.

Ewa, K; Kryrowska, S (2010). Geothermal exploration in Nigeria. Proceedings World Geothermal Congress. Zaria, Nigeria, (3); 1 - 59.

Jones, PH (2010). Geothermal and hydrocarbon regimes, Northern Gulf of Mexico Basin: Proceedings of the first Geo pressured Geothermal Energy Conference. Louisiana State University, Baton Rouge.

Lawal, TO; Nwankwo, LI (2017). Evaluation of the Depth to the bottom of magnetic sources and Heat flow from High Resolution Aeromagnetic (HRAM) Data of part of Nigeria sector of Chad basin Arabian J. Geosciences. (10): $1-12$.
Lawal, TO; Nwankwo, LI; Akoshile, CO (2015). Wavelet Analysis of Aeromagnetic Data of Chad Basin, Nigeria. The Afr. Rev. Phys. (10): 10 - 16

Nwankwo, LI; Shehu, AT (2015). Evaluation of Curiepoint depths, geothermal gradients and near-surface heat flow from high-resolution aeromagnetic (HRAM) data of the entire Sokoto Basin, Nigeria. $J$. of Volcanology and Geothermal Res. 30545 - 55.

Nwankwo LI (2015). Estimation of depths to the bottom of magnetic sources and ensuing geothermal parameters from aeromagnetic data of Upper Sokoto Basin, Nigeria. Geothermics 54: 76 - 81

Nwankwo, CN; Ekine, AS; Nwosu, LI (2009). Estimation of the Heat Flow Variation in the Chad Basin, Nigeria. J. Appl. Sci. Environ. Manage.. (13): 73-80

Okubo, Y; Graf, FJ; Hansent, RO; Ogawa, K; Tsu, H (1985). Curie point depths of the Island of Kyushu and surrounding areas, Japan. Geophysics; 4(53): 81 $-94$.

Ravat, D; Pignatelli, A; Nicolosi, I; Chiappini, M (2007). A study of spectral method of estimating the depth to the bottom of magnetic sources from near-surface magnetic anomaly data. Geophys. J. Int. 169: 421 434.

Ross, HE; Blakely, RJ; Zoback, MD (2006). Testing the use of aeromagnetic data for the determination of Curie depth in California. Geophysics: 71 (5); 151 159.

Salk, M; Pamukcu, O; Kaftan, I (2005). Determination of the Curie Point Depth and Heat Flow from Magsat Data of Western Anatolia. J. Balk. Geophy. Soc. 8 (4); $149-160$

Spector, A; Grant, FS (1970). Statistical models for interpreting aeromagnetic data. Geophysics; (35); 293-302.

Tanaka, A; Okubo, Y; Matsubayashi, O (1999). Curie point depth based on spectrum analysis of the magnetic anomaly data in East and Southeast Asia. Technophysics (306):461 - 70. World Energy Council (2016): World Energy Resources Geothermal. 